\title{
Investigation and Analysis of the Current Situation of Students' Sports Life in Chinese Culture University of Taipei
}

\author{
Qiang Yan ${ }^{1, a}$, Teng $\mathrm{Ma}^{2}$ \\ ${ }^{1,2}$ College of Physical Education, Yulin University 719000
}

\begin{abstract}
Through the investigation and analysis of the students' sports life in the Chinese Culture University of Taipei, it can reflect that different regional cultures have different cultural characteristics. The investigation and analysis of the students' participation in sports activities, the degree of awareness, the selection of sports items, the motivation of participating in sports activities and the related sports consumption, is based on the Chinese Culture University of Taipei. This paper finds out the problems existing in the students' sports life of Chinese Culture University and puts forward some reasonable suggestions.
\end{abstract}

\section{Preface}

A side water and soil raises a side people. Different regional cultures make different cultural life. Everything has its source and basis, can not be produced without ground, the results are inextricably and sports culture is no exception. China's Taiwan has its own unique sports culture. In today's fast-developing society, with the continuous development of sports, we find that daily sports activities play an increasingly important role in people's lives. The value function of sports will be continuously recognized and deepened as people's living needs are improved, thus scientifically improving the consumption investment, equipment selection and sports culture awareness of sports. In addition, the construction of sports culture in a region is related to its economic level, political strategy, and customs. Taiwan is one of China's treasure islands, flowing with the cultural heritage of the Chinese nation, and the unique treasure island region has its unique customs and culture. There are many types of sports life, and there are many attitudes, that is, sports life has become diversified, and the methods and means of each individual' $\mathrm{s}$ sports life are also different. This paper analyzes the current situation of students' sports life in the Chinese Culture University of Taipei, and aims to provide a new model and reference sample for the sports culture construction of Yulin University.

\section{Research objects and research methods}

\subsection{Research objects}

160 male and female students from Chinese Culture
University of Taipei are randomly selected as the research objects.

\subsection{Research methods}

This paper employs the methods of literature review, questionnaire, interview and mathematical statistics to investigate and study the participation of students in sports life in the Chinese Culture University of Taipei, as well as the selection of sports related items and consumption.

\section{Research results and analysis}

\subsection{An investigation of students' participation in sports life in China Culture University of Taipei}

Table 1. A questionnaire survey on students' cognition of sports life in Taipei Chinese Culture University.

\begin{tabular}{|c|c|c|}
\hline Participation & Male & Female \\
\hline $\begin{array}{c}\text { Frequently participate in sports } \\
\text { activities }\end{array}$ & 52 & 42 \\
\hline $\begin{array}{c}\text { Generally participate in sports } \\
\text { activities }\end{array}$ & 27 & 18 \\
\hline $\begin{array}{c}\text { Basically do not participate in } \\
\text { sports activities }\end{array}$ & 5 & 11 \\
\hline
\end{tabular}

The survey shows that 52 males with a very rich and frequent sports life account for $33 \%$ of the total number of students, and $62 \%$ of the total number of males. 42 female students make up about $27 \%$ of the total, accounting for $59 \%$ of the total number of females; The generally sports life of the 27 males accounts for $17 \%$ of the total number, accounting for $32 \%$ of the total number

\footnotetext{
a Corresponding author: author@e-mail.org
} 
of males. 18 females make up $12 \%$ of the total number and $25 \%$ of the total number of females; In normal life, there are only 5 males who do not participate in sports activities, accounting for $3 \%$ of the total number, and 11 of the females are $7 \%$. It can be seen from these data that most of the students have a high degree of cognition and participation in sports life, and they regard sports as a part of life. Only a small number of students do not participate in sports-related activities in their normal life, and they have a relatively shallow understanding of participating in sports life, among which females are more.

\subsection{The time of students participating in sports activities in Taipei Chinese Culture University}

Table 2 A survey of students' daily participation in sports activities

\begin{tabular}{cccccc}
\hline Option & $\begin{array}{c}\text { Above 100 } \\
\text { minutes }\end{array}$ & $\begin{array}{c}75-100 \\
\text { minutes }\end{array}$ & $\begin{array}{c}50-75 \\
\text { minutes }\end{array}$ & $\begin{array}{c}25-50 \\
\text { minutes }\end{array}$ & $\begin{array}{c}\text { Under 25 } \\
\text { minutes }\end{array}$ \\
\hline $\begin{array}{c}\text { Number } \\
\text { of males }\end{array}$ & 28 & 24 & 17 & 10 & 5 \\
$\begin{array}{c}\text { Number } \\
\text { of } \\
\text { females }\end{array}$ & 13 & 21 & 19 & 11 & 7 \\
\hline
\end{tabular}

The survey shows that the amount of time that college students participate in sports activities in college life can directly reflect the fullness of a student in college life. And the above data indicates that the majority of students' sports life is relatively frequent. Males have 69 people who have more than 50 minutes of physical activity per day, accounting for $82 \%$ of the total number of males. Only 15 people have less than 50 minutes of physical activity per day, about $18 \%$ of the total number of males. The daily physical activity of females is basically the same as that of males. Among them, 53 people have more than 50 minutes of physical activity per day, accounting for $75 \%$ of the total number of females. But only 18 people have less than 50 minutes of daily physical activity, accounting for about $25 \%$ of the total number of females, more than males under 50 minutes. Among the 155 students who participates in the sports activities of the Chinese Culture University, the proportion of males participating in sports activities is slightly higher than that of females, but the difference is not very large. It shows that the participation of males and females in Chinese Culture University is basically same.

\subsection{Students' attitudes towards sports activities at China Culture University in Taipei}

Table 3 Students' attitude towards sports activities

\begin{tabular}{ccccc}
\hline $\begin{array}{c}\text { Sex and } \\
\text { number of } \\
\text { people }\end{array}$ & $\begin{array}{c}\text { Like very } \\
\text { much }\end{array}$ & Like & $\begin{array}{c}\text { Generally } \\
\text { like }\end{array}$ & Dislike \\
\hline $\begin{array}{c}\text { Number of } \\
\text { males }\end{array}$ & 35 & 27 & 16 & 6 \\
$\begin{array}{c}\text { Number of } \\
\text { females }\end{array}$ & 28 & 24 & 15 & 4 \\
\hline
\end{tabular}

The survey shows that 62 males like or like sports activities very much, accounting for $74 \%$ of the total number of males. There are 22 students who generally or dislike towards sports activities, accounting for $26 \%$ of the total number of males. There are 52 females who like or like sports activities very much, accounting for $73 \%$ of the female students, that is, about $27 \%$ of the females who generally like or dislike sports activities. This shows that the attitudes of males and females of the Chinese Culture University are basically same for sports activities.

\subsection{Investigation on the selection of students participating in sports activities in Chinese Culture University of Taipei}

Table 4 Questionnaire for the selection of students participating in sports activities at the Chinese Culture University in Taipei (multiple choices available)

\begin{tabular}{ccccccccc}
\hline Option & $\begin{array}{c}\text { Base- } \\
\text { ball }\end{array}$ & $\begin{array}{c}\text { Basket- } \\
\text { ball }\end{array}$ & $\begin{array}{c}\text { Volley- } \\
\text { ball }\end{array}$ & $\begin{array}{c}\text { Foot- } \\
\text { ball }\end{array}$ & Golf & $\begin{array}{c}\text { Table } \\
\text { tennis }\end{array}$ & $\begin{array}{c}\text { Swim- } \\
\text { ming }\end{array}$ & Dance \\
\hline $\begin{array}{c}\text { Num- } \\
\text { ber of }\end{array}$ & 27 & 14 & 6 & 7 & 8 & 9 & 13 & 9 \\
males & & & & & & & & \\
$\begin{array}{c}\text { Num- } \\
\text { ber of } \\
\text { fema- } \\
\text { les }\end{array}$ & 18 & 11 & 24 & 1 & 6 & 2 & 9 & 26 \\
\hline
\end{tabular}

The survey shows that a large proportion of students like baseball, 45 males and females like baseball, accounting for $29 \%$ of the total number of them. Among them, male students account for about $60 \%$, and males prefer baseball more; The second is the dance of the females. There are 26 females who choose to dance. The number of females who like volleyball programs is high, and 24 females choose volleyball programs, accounting for about $34 \%$ of the total number of females; The number of females' dance and volleyball choices accounts for $52 \%$ of the total number of females' choices, which is more than half of the total number of females' choices; The difference in the proportion of other projects is not obvious, such as basketball, golf, table tennis, swimming. However, compared to football, they prefer to choose a slightly lower football project. Only 8 people like football, accounting for about $5 \%$ of the total number of males and females, accounting for about $4 \%$ of the total number of choices. It can be seen from the above data that it is obvious that the number of baseball projects and dance projects is much larger. Baseball is closely related to the local sports culture of Taiwan. Dancing is more popular with females, which is closely related to the nature of females.

\subsection{Investigation on sports-related consumption of students in Chinese Culture University of Taipei}

Table 5 Sports-related consumption distribution (unit: yuan)

\begin{tabular}{ccccc}
\hline Option & Clothing & Equipment & $\begin{array}{c}\text { Course and } \\
\text { competition } \\
\text { ticket fees }\end{array}$ & $\begin{array}{c}\text { Other sports } \\
\text {-related } \\
\text { consumption }\end{array}$ \\
\hline $\begin{array}{c}\text { Monthly } \\
\text { consumption } \\
\text { per capita }\end{array}$ & $400-600$ & $100-200$ & $200-400$ & $300-500$ \\
\hline
\end{tabular}

The survey shows that the equipment is the minimum 
amount of consumption, between 100 and 200 RMB. Costs related to clothing, courses and tickets for competitions, and other sports-related expenses range from 200 to 600 . The concentration of college students' sports consumption projects reflects the college students' understanding of sports life, and it is also conducive to college students' life enrichment, physical health, and physical and mental development. Of course, the economic and cultural foundation also determines the superstructure, which determines the consumption situation. The Chinese Culture University is actually such a level of consumption, and its overall consumption is at a relatively high level.

\subsection{Factors affecting students' sports activities in Taipei Chinese Culture University}

Table 6 Factors affecting students' sports activities

\begin{tabular}{ccccc}
\hline Option & $\begin{array}{c}\text { Nobody } \\
\text { organizes } \\
\text { and guides }\end{array}$ & $\begin{array}{c}\text { No } \\
\text { time }\end{array}$ & $\begin{array}{c}\text { No } \\
\text { interest }\end{array}$ & $\begin{array}{c}\text { Venue } \\
\text { equipment }\end{array}$ \\
\hline $\begin{array}{c}\text { Number of } \\
\text { people } \\
\text { Percentage }\end{array}$ & 38 & 58 & 23 & 36 \\
\hline
\end{tabular}

The results show that there are 38 people without organization and guidance, accounting for $25 \%$ of the total number. There are 58 people who have no time, accounting for $37 \%$ of the total number, 23 people who are not interested, accounting for $15 \%$ of the total number, and 36 people due to venue equipment, accounting for $23 \%$ of the total. From these data, we can see that the number of people who have no time to play sports is very large and obvious, but the number of people who are not interested in sports is very small. Because of the equipment and no organization factor, the relative number is similar. There is a large number of people who do not have time to participate in sports activities, which is also related to the pressure of the school's cultural curriculum.

\subsection{The motivation of participating in sports activities at the Chinese Culture University of Taipei}

Table 7 Motivation to participate in extracurricular sports activities

\begin{tabular}{ccccc}
\hline $\begin{array}{c}\text { The } \\
\text { number } \\
\text { of gender }\end{array}$ & $\begin{array}{c}\text { Enriching } \\
\text { life }\end{array}$ & $\begin{array}{c}\text { Friendship } \\
\text { and } \\
\text { communica- } \\
\text { tion }\end{array}$ & $\begin{array}{c}\text { Fitness } \\
\text { and } \\
\text { bodybu- } \\
\text { ilding }\end{array}$ & $\begin{array}{c}\text { For } \\
\text { sports } \\
\text { related } \\
\text { exams }\end{array}$ \\
\hline $\begin{array}{c}\text { Number } \\
\text { of males }\end{array}$ & 26 & 15 & 33 & 11 \\
$\begin{array}{c}\text { Number } \\
\text { of } \\
\text { females }\end{array}$ & 16 & 8 & 40 & 7 \\
\hline
\end{tabular}

The survey shows that the number of males for fitness and bodybuilding accounts for about $33 \%$ of male students, and friendship and communication accounts for about $18 \%$ of male students. The number of males for sports-related examinations accounts for about $21 \%$ of male students, $13 \%$ of male students for fitness and bodybuilding, and $14 \%$ of male students for enriching life. The number of females accounts for about $44 \%$ of female students for fitness and bodybuilding, $17 \%$ for sportsrelated examinations, $13 \%$ for physical fitness, $15 \%$ for enriching life and $11 \%$ for friendship and communication. Male and female students have the largest number of fitness and bodybuilding, accounting for $38 \%$ of the total number. Secondly, the number of people is more for sports-related examinations, accounting for about $19 \%$ of the total number. It can be seen that the enthusiasm of Chinese Culture University students to participate in extracurricular sports activities is higher, and the awareness of lifelong sports is higher.

\section{Conclusion and suggestion}

\subsection{Conclusion}

3.1.1 Students from the Chinese Culture University in Taipei have a higher level of understanding and participation in sports and cultural life, and regard sports life as a part of life. Only a small number of students do not participate in sports-related activities in their normal life, and they have a lighter understanding of participating in sports life, among which females are more.

3.1.2 When the students of the Chinese Culture University in Taipei participate in sports activities every day, the proportion of boys participating in sports activities is slightly higher than that of girls, but the gap is not very large. Therefore, it is proved that the participation of boys and girls in the Chinese Culture University of Taipei City in sports life is basically the same.

3.1.3 The attitude of students to sports activities of the Chinese Culture University in Taipei is basically the same.

3.1.4 Through the survey of the selection of students participating in sports activities in the Chinese Culture University of Taipei, it can be concluded among the students of the Chinese Culture University in Taipei, there are more boys who like baseball and girls who like dance. Compared with other sports events, the gap is obvious.

3.1.5 According to the survey of students' sportsrelated consumption in the Chinese Culture University of Taipei, the sports-related consumption of Chinese Culture University students is at a relatively high level, which is also directly related to the local economic and cultural development. At the same time, it also reflects that Taipei's Chinese culture university students have a higher level of cognition on sports consumption and sports life.

3.1.6 The main factors affecting the sports activities of the students of Taipei Chinese Culture University are field equipment, no organization, and no time, but the number of people who are not interested in sports activities is less.

3.1.7 The motivation of students participating in sports activities at the Chinese Culture University in Taipei is mainly based on fitness, bodybuilding and 
enriching life. Therefore, it can be seen that the enthusiasm of Chinese Culture University students to participate in sports activities is higher, and the awareness of lifelong sports is higher.

3.1.8 The injuries in the sports activities of students of the Chinese Culture University in Taipei are mainly based on baseball and dance projects. However, the total number of injuries in other projects is also relatively serious. From a holistic perspective, $80 \%$ of students have had related sports injuries due to sports activities. Sports injuries are related to sports projects. Different sports have different damage parts and damage levels, and the frequency of damage is related to each person's participation in the sports. Students of the Chinese Culture University in Taipei City will cause a series of sports-related injuries and safety hazards in the rich and balance between work and rest.

\subsection{Suggestion}

3.2.1 Through this research, it is found that the sports life activities of students of the Chinese Culture University in Taipei are relatively frequent, which also has a great relationship with the sports culture activities of the school. But a large number or too frequent sports activities will indirectly affect students' academic performance. It is also necessary to suggest that sports activities should be appropriate and strike a proper frequent sports activities.

3.2.2 In the influencing factors of students participating in sports activities at the Chinese Culture University in Taipei, it can be seen that the factors of no guidance, venue equipment, and no time is very larger. Therefore, it is recommended that the school organize more guidance personnel or organizations of relevant sports activities, and strengthen the promotion of sports activities and improve the construction of sports venues and equipment.

3.2.3 The sports life activities of students at the
Chinese Culture University in Taipei are more frequent and rich, so the related sports injuries are still very serious. We should pay more attention to safety hazards and sports injuries in sports activities. School-related life organization teachers or physical education teachers should strengthen the basic common sense education on students' sports safety education and sports injury prevention. It is necessary to set up departments in the school to inquire and understand the problems of warmup and prevention of injuries before sports activities. For some sports facilities with potential safety hazards, the equipment should be inspected and repaired regularly.

\section{References}

1. Chen Yanyang. The Development and Characteristics of Sports in Hong Kong [J]. Journal of South China Normal University (Social Science Edition), 2001, (02): 23-25.

2. Wu Shubin. Research on the Development Model of Community Sports in Macao [J]. Journal of Physical Education, 2002, (06): 28-31.

3. Chen Linong. A Comparative Study of Competitive Sports in Hong Kong and Macau [J]. Journal of Beijing Sport University, 2006, (08): 1140-1142.

4. Huang Youli. A Study of the Development Strategy of Macau Sports in the Framework of One Country, Two Systems [D]. Beijing: Beijing Sport University, 2009, 75-76.

5. Cai Jun, Su Mingli, Zheng Min. Research on Sports Consumption Level and Development Strategy of Urban Residents in Shaanxi Province [J]. Journal of Xi'an Physical Education University, 2008, (06): 5455. 